\title{
EGGLAYING AND ALBUMEN GLAND COMPOSITION OF ARCHACHATINA MARGINATA DURING GROWTH PHASES
}

\author{
PUESTA DE HUEVOS Y COMPOSICIÓN DE LA GLÁNDULA DEL ALBUMEN DE \\ ARCHACHATINA MARGINATA DURANTE LAS FASES DE CRECIMIENTO
}

\author{
Ademolu, K.O. ${ }^{1 *}$; Taiwo, B.E. ${ }^{1}$; Jayeola, O.A. ${ }^{1}$ and Ajayi, $0 .{ }^{1}$ \\ 'Biological Sciences Department. University of Agriculture. Abeokuta. Nigeria. *kennyademolu@yahoo.com

\section{Additional KeYWORDS} \\ Snail.Reproductive capability. \\ Palabras Clave adicionales \\ Caracol. Capacidad reproductiva.
}

\section{SUMMARY}

The egg laying pattern and albumen gland composition in three growth phases of Archachatina marginata: snailet, juvenile and adult were investigated in this study. The juvenile stage laid the highest number of snails (9.3) followed by the adult stage (4.7), while no egg was laid by the snailet phase. However, the eggs laid by the adult phase were significantly $(p<0.05)$ heavier than those laid by the juvenile stage. The adult stage had the biggest albumen gland $(7.30 \pm 0.1 \mathrm{~cm})$ and the highest lipase, proteinase, $\alpha$-glucosidase, amylase and cellulase activities followed by the juvenile stage, while the snailet had the least values. However, results of organic composition of the albumen gland show that juvenile phase has a statistically higher protein, glucose and lipid composition than the other two growth phases. Correlation analysis showed a strong positive relationship between egg number and albumen gland glucose, protein and lipid composition It can thus be inferred that juvenile stage of $A$. marginata has the best reproductive capability and potential.

\section{RESUMEN}

Se analizó el modelo de puesta y la composición de las glándulas del albumen de Archachatina marginata en tres fases de crecimiento: cría, juvenil y adulto. La puesta fue mayor en la etapa juvenil $(9,3)$ seguida de la adulta $(4,7)$, no hubo puesta de huevos en las crías. Los huevos de la etapa adulta fueron más pesados $(p<0,05)$ que los de la juvenil. Los adultos tuvieron las glándulas de albumen más grandes $(7,30 \mathrm{~cm})$ y las mayores actividades lipasa, proteinasa, $\alpha$-glucosidasa, amilasa y cellulasa, seguidas en orden decreciente por juveniles y crías. En la fase juvenil hay mayor concentración de proteína, glucosa y lípidos en la glándula del albumen. Se registraron fuertes relaciones positivas entre número de huevos, y glucosa, proteína y lípidos de la glándula del albumen. Puede inferirse que en la etapa juvenil de $A$. marginata, son mayores el potencial y la capacidad reproductiva.

\section{INTRODUCTION}

The search for cheap animal protein by citizens of developing countries like Nigeria is enormous because of the fluctuating economy. In recent time, attention has been shifted to a new branch of study, that is, micro livestock- the rearing of invertebrate and lower animals like grasscutters, rabbits and snails. Snails are unique because of their simple nature and ability to feed on wide varieties of feeds including household wastes.

Generally, snails pass through three growth stages namely: Infantile (snailet), juvenile and mature (adult) phase (South, 1992). Ademolu et al. (2009) had earlier observed that the juvenile phase of $A$. marginata recorded a significantly higher concentration of glucose and lipids in their haemolymph than other growth phases.

Studies by different scientists have shown that size and total number of eggs 
laid by snails differ from one species to another and various reasons have been adduced for this observation, namely: tract size (Idokogi and Osinowo, 1998), genetic make-up and haemolymph characteristics (Ademolu et al., 2009). Nevertheless, the knowledge of the properties of the albumen gland - site of egg coating and fertilization can provide an insight into this age variation in egg laying pattern and ultimately assist in better production of $A$. marginata in captivity. The thrust of this work is to examine the egg laying pattern and albumen gland composition of $A$. marginata during three growth phases.

\section{MATERIALSANDMETHODS}

The study was carried out in the Animal House of the Department of Biological Sciences, Federal University of Agriculture, Abeokuta, Nigeria (7010'N and 302'E). Nine plastic cages $(30 \times 40 \times 24 \mathrm{~cm})$ were filled with top loamy soil up to $5 \mathrm{~cm}$ before introducing the snails.

A total of forty-five (45) Giant African land snails - A. marginata were purchased from the snail pen of the Department of Forestry and Wildlife Management. The snails were in three growth phases namely: snailet $( \pm 100.5 \mathrm{~g})$, juvenile $( \pm 133.2 \mathrm{~g})$ and adult $( \pm 211.7 \mathrm{~g})$ as earlier described by Idokogi and Osinowo (1998). The cages housing the snails were cleaned every day before feeding and the top loamy soil replaced every 2 weeks. The snails were fed ad libitum for 12 week with fresh pawpaw leaves and water. The eggs laid during the experiment were recorded and incubated in cans containing loamy soil.

Snails were dissected following the method of Segun (1975). The albumen gland was carefully removed from the hermaphroditic duct with a pair of sterile scissor into a clean petri dish. The colour and texture of the gland was observed by feeling with the fingers. The weight and width of albumen gland from the three groups were taken by sensitive weighing balance (PM-Mettler $-\mathrm{K})$ and tape rule respectively.

Nine (9) snails from each group were used for the chemical analysis of the albumen gland. The activities of amylase, $\alpha$ glucosidase, cellulase, lipase and proteinase were determined following the method of AOAC (1990). Similarly, the organic contents of the albumen gland were determined as follows - protein was analysed by Biuret method (Henry et al., 1977), while glucose was determined colorimetrically (Baumniger, 1974). Lipid content was assayed by method of Grant (1987).

All data collected from this study were subjected to one-way analysis of variance (ANOVA) and wherever there were significant values, means separation was done by SNK-test. Correlation analysis was also done to determine the relationship between the egg number and the organic content of the albumen gland.

\section{RESULTS}

The juvenile stage laid the highest number of eggs followed by the adult stage, while the snailet phase did not lay egg at all. However, the adult snails laid significantly bigger eggs (table I). Also, the adult stage had the heaviest and biggest albumen gland followed by the juvenile stage the smallest was observed in the snailet (table I). The color of the albumen gland of the experimental snails varies from cream color in snailet phase to golden yellow in the adult phase (table I). The shape and texture of the gland are bean-like and soft respectively for the 3 phases of life.

The albumen gland of adult $A$. marginata recorded higher enzymatic activities for all the enzymes than the other two phases of development (table II). Statistical analysis showed that the albumen gland of the juvenile stage had a significantly $(\mathrm{p}<0.05)$ higher concentrations of lipid and glucose than both adult and snailet phases. Additional analysis $\left(r^{2}\right)$ of the number of eggs 
Table I. Egg laying pattern and albumen gland in A.marginata. (Producción de huevos y glándula del albumen en $A$. marginata).

\begin{tabular}{lccc}
\hline & Snailet & Juvenile & Adult \\
\hline Egg laying & & & \\
eggs laid & 0.00 & $9.3 \pm 0.02^{\mathrm{a}}$ & $4.7 \pm 0.01^{\mathrm{b}}$ \\
egg weight, g & 0.00 & $1.93 \pm 0.1^{\mathrm{b}}$ & $3.70 \pm 0.03^{\mathrm{a}}$ \\
Albumen gland & & & \\
Weight, g & $1.0^{\mathrm{c}} \pm 0.01$ & $3.4^{\mathrm{b}} \pm 0.3$ & $11.0^{\mathrm{a}} \pm 0.1$ \\
Length, cm & $2.5^{\mathrm{c}} \pm 0.1$ & $4.6^{\mathrm{b}} \pm 0.2$ & $7.3^{\mathrm{a}} \pm 0.1$ \\
Width, cm & $0.7 \pm 0.03$ & $1.0 \pm 0.02$ & $1.6 \pm 0.4$ \\
Colour & Cream & Cream & Golden yellow \\
Texture & Soft & Soft & Soft \\
Shape & Bean & Bean & Bean \\
\hline
\end{tabular}

abcMean values on the same row having the same superscript are not significantly different $(p>0.05)$.

laid and the organic concentration of the albumen gland revealed a strong positive relationship between them. The $\mathrm{r}^{2}$ values for glucose, protein and lipid were $0.99,0.61$ and 0.90 respectively.

Table II. Enzymatic activities and composition of the albumen gland of A. marginata. (Actividad enzimática y composición de la glándula del albumen de $A$. marginata).

\begin{tabular}{|c|c|c|c|}
\hline & Snailet & Juvenile & Adult \\
\hline \multicolumn{4}{|l|}{ Enzymes (nmol) } \\
\hline Cellulase & $3.3 \pm 0.2$ & $5.4 \pm 2.1$ & $6.2 \pm 1.1$ \\
\hline Amylase & $5.1 \pm 0.1$ & $6.5 \pm 0.4$ & $7.5 \pm 0.1$ \\
\hline$\alpha$-glucosidase & $7.1 \pm 0.1^{b}$ & $8.5 \pm 0.3^{\mathrm{ab}}$ & $9.8 \pm 0.1^{a}$ \\
\hline Lipase & $2.1 \pm 0.3^{\mathrm{b}}$ & $4.3 \pm 0.1^{\mathrm{ab}}$ & $5.9 \pm 0.2^{a}$ \\
\hline Proteinase & $9.3 \pm 0.1$ & $10.9 \pm 0.7$ & $11.6 \pm 0.5$ \\
\hline \multicolumn{4}{|l|}{ Composition } \\
\hline Protein, g/L & $30.0 \pm 0.3^{b}$ & $58.6 \pm 1.3^{a}$ & $42.4 \pm 0.4^{\mathrm{ab}}$ \\
\hline \multicolumn{4}{|c|}{ Glucose, mg/dL $6.0 \pm 0.1^{\mathrm{b}} \quad 16.10 \pm 1$} \\
\hline Lipids, mg/dL & $54.4 \pm 0.2^{\mathrm{b}}$ & $89.30 \pm 0.6^{a}$ & $62.1 \pm 0.2^{b}$ \\
\hline
\end{tabular}

abMean values on the same row having the same superscript are not significantly different $(p>0.05)$.

\section{DISCUSSION}

The egg laying pattern of different phases of development of $A$. marginata reveals that the juvenile stage laid the highest number of eggs followed by the adult stage. However, the smaller number of eggs laid at the adult stage might possibly be due to degenerating of some reproductive organs due to age. The juvenile stage is a growing and active phase of snails and thus has the ability to produce higher number of eggs. Idokogi and Osinowo (1998) reported that snailets have rudimentary reproductive structures, suggesting that they were not sexually matured and this might explain their inability to lay any egg. The higher enzymatic activities of the adult phase albumen gland suggests the ability of the gland cells to digest the substrates of those enzymes better and this might likely explains the bigger sizes of the eggs laid by them as there are more nutrients available for the growth of the eggs cells. In a related study, Maha et al. (2009) reported that steroid hormones were abundantly present in the tissues of Biomphalaria alexandrina snails while low levels were recorded in juvenile snails. The low level in juvenile stage probably indicates the commencement of reproductive activities unlike the adult stage where the process is well established.

The coloration of the albumen gland becomes intense as the snail ages suggesting level of growth. The color of tissues like muscles suggests their age and growth level (Odiete, 1999). Juvenile stage had a significantly higher concentration of glucose and lipid in its albumen gland relative to other stages of development. Similarly, a significantly higher concentration of glucose and lipids was reported in the haemolymph of juvenile A. marginata (Ademolu etal., 2009). Lipids and glucose are rich energy metabolites that supply the cells with much needed energy at this phase of development. The higher number of eggs laid during this phase might not have been unconnected to the 


\section{ADEMOLU, TAIWO, JAYEOLA AND AJAYI}

high concentration of these metabolites. The albumen gland organic composition might suggests the number of eggs laid by

\section{REFERENCES}

Ademolu, K.O.; Idowu, A.B. and Jayeola, O.A. 2009. Changes in Haemolymph Biochemical values during different growth phases in African giant land snail, Archachatina marginata (Swainson). Nig J Anim Prod, 36: 161-166.

AOAC. 1990. Association of official Analytical Chemsit. Ed. W. Horwitz. $13^{\text {th }}$ adition. Washington, D.C. 1141 pp.

Baumniger, R.N. 1974. Analytical Chemistry. Cambridge Press. London. pp. 83-85.

Grant, G.H. 1987. Amino acids and Protein: Fundamentals of clinical chemistry. WB Sander Company. Philadelphia. USA. pp. 326-329.

Henry, R.J.; Canon, D.C. and Winkalman, J.W. 1977. Clinical Chemistry: Principle and Technique $2^{\text {nd }}$ ed. Harper and Row Publishers. New York. pp. 54-56.

Idokogi, E.A. and Osinowo, O.A. 1998. Investigation on the reproductive system of the African land a particular snail, as there existed a strong positive relationship between albumen gland composition and number of eggs laid.

snail. Archachatina marginata. Proceeding on Silver Anniversary of Nigerian Society for Animal Production (NSAP). Abeokuta, 21-25 March. pp. 415-416.

Maha, R.; Abdul-Hamid, A.Z.; Mamlouk, E.T. and Said, N. 2009. Assessment of steroids during maturation and infection of Biomphalaria alexandrina snails, an intermediate host of Schistosoma mansoni. Biohealth Sc Bulletin, 1: 7-12.

Odiete, W.O. 1999. Basic Animal Physiology. Diversified Resources Ltd. Lagos.

Segun, O.A. 1975. The Giant Land Snail Archachatina (Calachatina) marginata (Swamson). Dissection guide of common tropical animal. Ethiope publishing house. Benin City. Nigeria. pp. 13-16.

South, A. 1992. Terrestrial Slugs: Biology, ecology and control. Chapman and Hall. USA. pp. 9-19. 